\title{
Purchasing power parity and efficiency of black market exchange rate in African countries
}

\begin{abstract}
This paper investigates the long-run dynamics of black and official exchange rates for ten African countries. Our major findings are, first, that parity holds more favorably when the black market rate is used to validate the purchasing power parity hypothesis. The evidence supports the notion that the speed of adjustment is much faster in the black market than in the official market. Second, the two rates are connected in the long run, with the official rate adjusting toward the black market rate for the majority of cases. Finally, we find the long-run informationally efficient hypothesis is supported in the majority of African countries.
\end{abstract}

Keyword: African countries; Black market exchange rate; Bounds tests; Purchasing power parity 